\title{
Just Wrestle: How We Evolved Through Rough And Tumble Play
}

Rafe Kelley, Evolve Move Play; rafe@evolvemoveplay.com

Beth Kelley, Evolve Move Play; m.elizabeth.kelley@gmail.com

Keywords: roughhousing, physical play, movement \& health, physicality \& cognition

\section{Introduction}

Rough and tumble play has been defined as physically vigorous behaviors, such as chase and play fighting, that are accompanied by positive feelings between the players $^{[1]}$. The authors argue that rough and tumble play is an important component of the ancestral health mismatch. While diet, sun exposure, sleep, and other lifestyle factors have received the lion's share of attention and study in the ancestral mismatch hypothesis, there is a growing understanding that movement may also be a primary factor in the ancestral mismatch problem ${ }^{[2][3]}$. Less attention has been paid to the role of play as a primary motivating system for movement, and an educational impulse that has implications across a huge range of psychosocial and motor development ${ }^{[4][5][6]}$.

Rough and tumble play is arguably a heavily repressed form of play ${ }^{[4][5][6]}$ and yet at the same time a truly fundamental and powerful form of play ${ }^{[4][5][7]}$. Rough and tumble play has its own dedicated neural networks in the brains ${ }^{[7]}$, is universal in all mammals, and has antecedents that are found throughout the group of bilateral animals, including birds, reptiles, and crustaceans ${ }^{[8][9]}$. Rough and tumble play is a key system for humans to develop physical coordination, strength, agility, spatial awareness, risk management, emotional management, social negotiation, cooperation, and moral systems that deserves further examination.

\section{Origins \& Benefits of Roughhousing}

Play is intrinsically rewarding to humans ${ }^{[3][6][7]}$; and has been previously argued to be one of evolution's most powerful solutions for helping animals develop into physically strong, socially well-adjusted, and cognitively flexible adults $^{[4][5][7][8][9][10]}$. Rough and tumble play is arguably the oldest form of play, with origins that go back at least 160 million years ${ }^{[7]}$. Play also has a distinct motivation circuit, like food seeking, dominance, or sex; it is one of our fundamental means of releasing rewarding neurohormones like dopamine, endorphins, and opioids ${ }^{[11][12]}$. 
It has been demonstrated that humans need movement to develop normally ${ }^{[2][13][14]}$, and humans evolved to develop movement through play ${ }^{[15]}$. Among other lessons, rough and tumble play teaches humans the limits of their bodies, the way other bodies move and interact with them, how to develop rhythm and coordination, the experience of both physical and psychological painful sensations without direct threat or harm to the body and how to deal with that pain, how to empathize with others, and how to create positive sum interactions with others ${ }^{[8][16][17][18]}$.

Rough and tumble play has been found to be essential for physically mapping the body in infancy and toddlerhood, and understanding personal physical safety ranging from bigger locomotive challenges like when and where to balance, to smaller locomotive procedures like knowing how hard to high-five a friend $[16][19][20][21]$. Other studies demonstrate the primal drive for humans and primates to play ${ }^{[8][15]}$; Berghänel et al. ${ }^{[22]}$ identified that juvenile macaques, particularly males, that focused on locomotor play in turn accelerated their motor skill acquisition and mastery, at times in exchange for slightly delaying their own physical growth.

Some form of wrestling is in fact common across much of the animal kingdom as a way to resolve dominance hierarchies, as rough and tumble play is a way to develop a sense of who is stronger without having to actually risk true physical harm $^{[8][18]}$. Roughhousing also has a primary role in the development of social negotiation $^{[14][16][23]}$. Panksepp ${ }^{[7]}$ demonstrated weaker rats will invite play with stronger rats only as long as the dominant rat allows the weaker one to win at least $30 \%$ of the time. This drive to play creates a game that rewards prosocial behavior. In order for the stronger rat to choose to lose it must have some moral sense about the other rat, it has to care about how someone else responds. This kind of cooperation is also found in humans, and has been demonstrated to be at the root of humans' learning to cooperate. These and other studies also suggest that altruism co-evolved with rough and tumble play ${ }^{[13][14][15]}$.

Play has often been portrayed by modern society as something unnecessary and trivial for adults ${ }^{[4][24]}$. However, spontaneous interactive physical play has been documented in all primates as adults, and humans are in fact the most playful across their lifespan ${ }^{[8][10]}$. There is strong evidence that cross-generational play has numerous benefits for both adults and children ${ }^{[4][5][17]}$; St. George et al. ${ }^{[25]}$ found that fathers who engaged in rough and tumble play with their children resulted in children engaging in safer risk taking and less injury overall. Gaumon $\&$ Paquette $^{[26]}$ identified that fathers roughhousing with their children negatively predicted internalizing behavior disorders. 


\section{Consequences of a Lack of Roughhousing}

Numerous studies ${ }^{[4][5][6][17]}$ have found that a lack of rough and tumble play is correlated to a host of physical, emotional, and developmental problems. Several studies have found that without physical play adults' brains and bodies deteriorate more quickly ${ }^{[5][18][21][24]}$. Brown ${ }^{[4]}$ found that a lack of play was a primary factor in predicting criminal behavior among murderers in Texas prisons. Children and adults that do not have some kind of physical play outlet have been shown to experience higher rates of isolation, depression, ill physical health ${ }^{[2][4][6][9][24]}$, and mental decline in older adults ${ }^{[27]}$.

Unfortunately, recess and tactile learning activities are being shortened or eliminated from schools at all ages ${ }^{[6][28]}$. Several studies have found modern social systems and current views on roughhousing are creating environments where play, and specifically rough and tumble play, is being eliminated, penalized, and in some cases criminalized at a very young age ${ }^{[29][30][31]}$, making unstructured physical play a liability rather than a core curriculum. Adults often attempt to replace children's rough and tumble play with sports or other structured physical activities; however the majority of American team sports or martial arts were developed at a time when rough and tumble play was far more common in children's lives ${ }^{[5][6][14][15]}$; therefore the authors hypothesize the pedagogy of most of these systems is unconsciously rooted in an assumption that children would develop normally through play before being put into sports or disciplines ${ }^{[5]}$, and that children are therefore still not receiving the foundational training that unstructured rough and tumble play provides despite their involvement in team sports $^{[4][6][7][16][17][21][28]}$.

\section{Benefits from Re-Introducing Roughhousing}

Play research across all animals has demonstrated that the benefits of rough and tumble play can be adopted and cultivated at any age; the findings have included improved spatial and environmental awareness, cognitive plasticity, increased lifespan and quality of life, and improved social connection with locomotor play adopted at any age ${ }^{[1][2][4][10][15][21][27]}$. Brown ${ }^{[4]}$ found that roughhouse playing together helped couples rekindle their relationship and explore other forms of emotional intimacy.

The authors' own work in teaching people the principles of rough and tumble play and exposing them to roughhousing has had effects far beyond their expectations. They have found that people who have not roughhoused in a while, or ever, often 
have an aversion to roughhousing, thinking it is dangerous or they will hurt the other person or themselves. As a consequence, within Evolve Move Play seminars the focus is instead on fundamental skills in sensitivity to seminar participants' partners, how to build rapport through movement and touch, how to recognize how we are internally responding to the intensity of interaction, and how to build a vocabulary of games and movements so they can play in a positive developmental, neurologically beneficial way. Students have reported after the seminars how the exercises practiced during the workshops improved their relationships with their children, their spouse, their sex life, and their performance in sport or martial $\operatorname{arts}^{[32][33]}$.

\section{Conclusion}

The authors have argued how roughhousing is an essential part of our primal, ancestral human development. They also argue that modern society has suppressed it down and out of everyday behaviors. They have demonstrated the need and value of roughhousing, and consequences of depriving humans of roughhousing. They also identified benefits of reintroducing roughhousing to regular physical practice, and possible approaches for reintroduction. Their hope is that this paper inspires people to consider a lack of rough and tumble play as an element of the ancestral mismatch problem, and that more ancestral lifestyle researchers and movement practitioners explore the benefits of roughhousing and adopt rough and tumble play into their practice.

\section{References}

1. Pellegrini \& Smith (1998). Physical Activity Play: Consensus and Debate. Child Development 69(3):609-610. Society for Research in Child Development.

2. Bowman, K. (2014). Expanded version 2017. Move Your DNA: Restore Your Health Through Natural Movement. Propriometrics Press.

3. Leiberman, D. (2014). The Story of the Human Body: Evolution, Health, and Disease. Vintage Press.

4. Brown, S. (2009). Play: How it Shapes the Brain, Opens the Imagination, and Invigorates the Soul. Penguin Books.

5. Forencich, F. (2001). Play As If Your Life Depends On It: Functional Exercise \& Living For Homo Sapiens. Seattle, WA: AtlasBooks/Go Animal.

6. Gray, P. (2013). Free to Learn: Why Unleashing the Instinct to Play Will Make Our Children Happier, More Self-Reliant, and Better Students for Life. Basic Books Publishing.

7. Panksepp, J. (1998). Affective Neuroscience: The Foundations of Human and Animal Emotions (Series in Affective Science). Oxford University Press.

8. Bekoff, M. \& Byers, J.A. Eds. (1998). Animal Play: Evolutionary, Comparative, and Ecological Perspectives. Cambridge: Cambridge University Press. 
9. Kelley, M.E. (2011). Move like a kid again: An analysis of Parkour as free-form adult play. WWU Masters Thesis Collection. 165.

10. Pellis, S.M. and Iwaniuk, A.N. (2000). Adult-adult play in primates: A comparative analysis of its origin, distribution, and evolution. Ethology. 106:1083-1104.

11. Panksepp, J. (1993). Rough and tumble play: A fundamental brain process. In MacDonald, K., Ed., SUNY series, children's play in society. Parent-child play: Descriptions and implications. pp. 147-184. Albany, NY: State University of New York Press.

12. Vanderschuren, L. J. M. J. (2010). "How the Brain Makes Play Fun.” The American Journal of Play. Board of Trustees of the Univ. of Illinois.

13. Fry, D. (2014). "The Environment of Evolutionary Adaptedness, rough-and-tumble play, and the selection of restraint in human aggression." Chapter 7 In Ancestral Landscapes in Human Evolution: Culture, Childrearing and Social Wellbeing. Eds. Narváez, D., Valentino, K., Fuentes, A. Oxford University Press.

14. Pellegrini, A. D. (2005). Recess: Its Role in Education and Development. Mahwah, N.J.: L. Erlbaum Associates.

15. Burghardt, G. M. (2001). Play: Attributes and neural substrates. In Blass, E.M. Ed., Handbook of behavioral neurobiology. Developmental psychobiology, developmental neurobiology and behavioral ecology: Mechanisms and early principles. 13:327-366. New York: Kluwer Academic/Plenum.

16. Bekoff, M. (2004). Wild justice and fair play: cooperation, forgiveness, and morality in animals. Biology and Philosophy. September 2004, 19(4):489-520. Netherlands: Kluwer Academic Publishers.

17. Peterson, J.B., Flanders, J. (2005). Play and the regulation of aggression. In Tremblay, R.E., Hartup, W.H. \& Archer, J. Eds. Developmental origins of aggression. pp. 133-157. New York: Guilford Press.

18. Pellegrini, A. D., Dupuis, D., \& Smith, P. K. (2007). Play in evolution and development. Developmental Review, 27:261-276.

19. Zeman J, Cassano M, Perry-Parrish C, Stegall S. (2006). Emotion regulation in children and adolescents. J Dev Behav Pediatr. 27:155-168. [PubMed]

20. Scott, Eric and Panksepp, Jaak (2003). Rough-and-Tumble Play in Human Children. Aggressive Behavior, 29:539-551.

21. Sheets-Johnstone, M. (1999/exp. 2nd ed. 2011). The Primacy of Movement. Amsterdam/Philadelphia: John Benjamins University Press.

22. Berghänel, A., Schülke, O., Ostner, J. (2015). Locomotor play drives motor skill acquisition at the expense of growth: A life history trade-off. Science Advances. 1.10.1126/sciadv.1500451.

23. Stahler, Daniel R. and Stahler, Douglas W. Smith, and Robert Landis (2002). The acceptance of a new breeding male into a wild wolf pack. Canadian Journal of Zoology. 80(2):360-365. NRC Research Press. Canada.

24. Whaley, D. (2007). "Life Span Development Approach to Studying Sport and Exercise Behavior" In Tenenbaum, Gershon \& Robert C. Eklund, Eds., Handbook of Sport Psychology. New York: Wiley.

25. St. George, J., Fletcher, R., Freeman, E., Paquette, D., \& Dumont, C. (2015). "Father-child interactions and children's risk of injury." Early Child Development and Care. 185(9):14091421.

26. Gaumon, S., Paquette, D. (2012). The father-child activation relationship and internalising disorders at preschool age. Early Child Development and Care: Unique Contributions of Mothering and Fathering to Children's Development. 183(3-4).

27. Whalley, L. (2001). The Ageing Brain. Columbia University Press. 
28. Eberle, S. (2017). "Better Learning Through Recess: Hands-On Play Switches On Minds." Psychology Today. Mar. 6, 2017.

29. Ernst, D. (2017). "Calif. elementary school bans kids from playing 'tag': 'It's something we all did as kids""; The Washington Times. Mar. 14, 2017.

30. Graff, A. (2015). "First grader suspended for shooting classmate with finger gun." SFGate. Mar. 5, 2015.

31. Hanson, H. (2015). "School District Bans Playing Tag, Claiming It's Not Safe For Kids," Huffington Post. Sept. 25, 2015.

32. "Is it OK if I Cry While I Jump?" blog post on Evolve Move Play website. Accessed 12/17/17. http://www.evolvemoveplay.com/is-it-ok-if-i-cry-while-i-jump/

33. Evolve Move Play Seminar testimonials. Accessed 12/17/17. http://www.evolvemoveplay.com/testimonials/ 